\title{
Online lektiehjælp \\ - Udvikling af en vejledningsdidaktik med pædagogisk designforskning som metode
}

\section{Jens Jørgen Hansen}

Lektor, ph.d.

Institut for Design og Kommunikation, Syddansk Universitet.

\section{Kirstin Remvig}

Informationsspecialist, cand.it.

Syddansk Universitetsbibliotek, Syddansk Universitet.
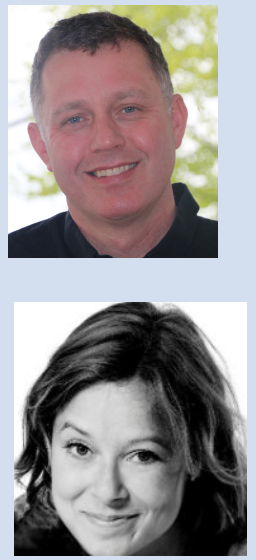


\section{Abstract}

Lektievejledning er en pædagogisk praksis i rivende udvikling med fokus på at støtte elever i at forstå og håndtere udfordringer i deres lektiearbejde. Lektievejledning er på den politiske dagsorden i skole og ungdomsuddannelser og tilbydes både internt af uddannelsesinstitutionerne samt af private og offentlige aktører. Men lektievejledning er ikke etableret som et teoretisk felt eller som en særlig vejledningskompetence. Der er således behov for at begrebsliggøre og udvikle teori om, hvad lektievejledning er, og hvordan vejledningsformen didaktisk kan håndteres. Mere konkret er udfordringen at udvikle et nuanceret fagsprog samt en modellering af feltet til forklaring af lektievejledningens komplekse praksis med det mål at udvikle og kvalificere lektievejledning som pædagogisk teori og pædagogisk praksis.

Denne artikel præsenterer resultatet af et forskningsprojekt, hvis mål er at udvikle en vejledningsdidaktik, herunder metoder, modeller og materialer for lektievejledning i regi af Lektier Online. Lektier Online er en organisation ved Statsbiblioteket i Århus, der tilbyder en online lektiecafe, hvor bl.a. gymnasieelever kan få hjælp af frivillige universitetsstuderende. Dette didaktiske design er et eksempel på, hvordan digitalisering og ny teknologi er en katalysator for udvikling af nye innovative læringsmiljøer og læringstilbud, der åbner fleksible og stedsuafhængige rum for læring, giver mulighed for samspil med aktører uden for skolens formelle rammer, og som er båret af integration af digitale teknologier i læringssituationen. Artiklen beskriver forskningsprocessen med at indkredse en vejledningsdidaktik for lektiehjælp samt udviklingen, konceptualiseringen, afprøvningen og evalueringen af en række vejledningsmodeller på grundlag af forskningsmetoden Pædagogisk designforskning og dens tradition for brugerdreven innovation. Artiklen beskriver for det første resultatet af forskningsprocessen i form af koncepter og modeller som: Lektievejlederens kompetenceprofil, Vejledningskompasset, Vejledningens scener og Vejledningsstrategimodellen - og evalueringen af disse modellers pædagogiske værdi. For det andet demonstrerer artiklen, hvordan forskerteamet metodisk har fortolket og udmøntet den pædagogiske designforsknings metode til udvikling af en vejledningsdidaktik.

\section{English abstract}

Homework counselling is a fast growing pedagogical practice where focus is on supporting students in understanding and handling challenges in their homework. Homework counselling is on the political agenda in schools and secondary schools and is offered both internally by the educational institutions as well as private and public operators. Homework counselling however is not established as a theoretical field or as a specific counselling competence. Hence there is a need to conceptualise and develop theories about what homework counselling is and how the form of counselling can be handled didactical. In concrete terms the challenge is to 
develop a nuanced terminology and a modelling of the field to explain the complex practices of homework counselling with the aim to develop and qualify homework counselling as a pedagogical theory and pedagogical practice.

This article presents the result of a research project, which aim is to develop a counselling didactic, including methods, models and materials for homework counselling within the framework of Homework Online. Homework Online is an organisation at the State Library in Aarhus, Denmark, which offers a place for online homework guidance where i.a. secondary school students can get help from volunteer university students. This didactical design is an example on how digitisation and new technology acts as a catalyst for developing new innovative learning environments and possibilities for learning, which opens flexible and spaces for learning irrespective of place, allowing interactions with external operators outside the formal school framework, and based on digital technology integration in the learning situation. The article describes the research process by increasing a counselling didactic for homework guidance plus the development, the conceptualisation, the testing and the evaluation of a number of counselling models based on the research method pedagogical design research and it's tradition for user driven innovation. The article describes firstly the results of the research process in form of the concepts and models: The Competence Profile of the Homework Counsellor, The Counselling Compass, The Counselling Scenes and The Counselling Strategy Model - and the evaluation of these models' pedagogical value. Secondly the article demonstrates how the research team have interpreted and implemented the pedagogical design research method in the development of a counselling didactic.

\section{Indledning}

Lektier Online er en organisation ledet af Statsbiblioteket i Århus, der tilbyder gratis online lektiehjælpstilbud for folkeskole- og gymnasieelever udført af frivillige universitetsstuderende. Vejledningen er organiseret i forskellige call-centre i de store universitetsbyer, hvor vejledningen foregår i et online-miljø. Lektier Online har eksisteret siden 2010 og drives i samarbejde med en række biblioteker, undervisnings- og forskningsinstitutioner, virksomheder, ministerier og styrelser. Lektier Onlines vision er ifølge deres hjemmeside: "[...] at gøre en forskel for danske skoleelever. Med eleven i centrum giver vi gratis lektiehjælp, der hjælper unge til at klare sig bedre i skolen og til at nå deres læringspotentiale." Lektier Onlines tilbud gælder for både skole- og gymnasieelever. Helt konkret tilbydes eleverne 30-45 minutters lektiehjælp, der 'live' foregår som en synkron online vejledning via kommunikationsplatformen http://www.lektieronline.dk. Eleverne kan her både tale og skrive med lektiehjælpere og demonstrere og forklare lektieopgaverne (for analyse af interaktion og kommunikation i 
den online vejledning se Dohn, Degnebolig, Lindhardt \& Lund, 2016 i nærværende tidsskrift).

Lektier kan defineres som "tasks assigned to students by school teachers that are meant to be carried out during non-school hours" (Cooper, 1989). Formålet med lektier er typisk at udvide læring udover klasserummet. Ved Lektier Online tilbydes eleven faglig vejleding i et online miljø, hvor kommunikationen med vejleder og elev er medieret af it-baserede kommunikationsteknologier (Richards \& Viganò, 2012). Vejledningen foregår gennem brug af tekst- og/eller lydbaserede synkrone kommunikationsformer og en delt skærm. Vejleder og elev kender ikke hinanden. Potentialet i online lektievejledning er, at elever har adgang til specialiseret ekspertise og faglig vejledning specifik rettet mod elevens faglige udfordringer. Lektier Online kan således beskrives som 'networked learning', hvor interaktionen mellem mennesker er medieret af it-teknologier (Carvalho \& Goodyear, 2014, p. 28).

Lektier Online er et eksempel på, hvordan digitalisering og ny teknologi er en katalysator for udvikling af nye innovative læringsmiljøer og læringstilbud, der åbner fleksible og stedsuafhængige rum for læring, giver mulighed for samspil med aktører uden for skolens formelle rammer, og som er båret af integration af digitale teknologier i læringssituationen (Hansen, 2016). Lektier Online kan opfattes som en digital lektiecafé, hvor lektievejledere fleksibelt og stedsuafhængigt kan vejlede og støtte elever i skolen med deres lektier og andre faglige udfordringer. Men teknologi er ikke i sig selv en 'driver' i forhold til at kvalificere de nye muligheder (Hansen, 2012a). Det afgørende er, hvordan de enkelte uddannelsesinstitutioner og de praktiske vejledere tænker om og praktiserer vejledning, og hvordan de teknologiske muligheder omsættes til koncepter, modeller, metoder og materialer. Udfordringen er således at udvikle en vejledningsdidaktik, hvor uddannelsesansvarlige og lektievejledere kan støttes og vejledes i at organisere og iscenesætte vejledningsforløb i et digitalt vejledningsmiljø.

En del af Lektier Onlines opgave er at uddanne frivillige lektiehjælpere, som typisk er universitetsstuderende rekrutteret fra forskellige universitetsmiljøer. Vi har som forskere undersøgt og bidraget til at udvikle Lektier Onlines koncept til uddannelse af frivillige lektiehjælpere på grundlag af forskningstilgangen pædagogisk designforskning. Vores forskningsspørgsmål er: Hvilken vejledningsdidaktik kan styrke Lektier Onlines uddannelse af lektievejledere samt kvalificere og udvikle lektievejledernes vejledningskompetencer? Udfordringen i uddannelse af frivillige lektievejledere er, at der ikke findes en etableret vejledningsdidaktik på dette område. En didaktik kan her forstås som en teoretisk reference for en vejleders praksis og kommunikation om praksis, jf. Erling Lars Dale (1998) teori om de tre niveauer af læreres professionskompetence: $\mathrm{k} 1$ handler om at håndtere professionens praksis, $\mathrm{k} 2 \mathrm{om}$ at planlægge praksis og k3 om kritisk at kommunikere om praksis på grundlag af didaktisk teori. En vejledningsdidaktik befinder sig her på k3 niveau. Udviklingen af en 
sådan didaktik forudsætter derfor en undersøgelse af, hvad en lektievejleder er, hvad en lektievejleder skal kunne, hvordan en lektievejleder skal/kan vejlede og på hvilket fagligt grundlag.

\section{Forskningsmetode - Pædagogisk designforskning}

I forskningsprojektet har vi benyttet metoden Pædagogisk designforskning som omdrejningspunkt for vores vidensproduktion. Pædagogisk designforskning (K. E. W. Bjørndal, 2014; Carlsen \& Hansen, 2015) er et dansk navn for den forskningstradition, der på engelsk har flere forskellige betegnelser Educational Design Research (Akker, Gravemeijer, McKenney, \& Nieveen, 2006; Hogue, 2013), Design Based Research (Amiel \& Reeves, 2008; Christensen, Gynther, \& Petersen, 2012; Cobb, Confrey, diSessa, Lehrer, \& Schauble, 2003; Reeves, 2006; Wang \& Hannafin, 2005) og Design Research (Gravemeijer \& Cobb, 2006). The Design-Based Research Collective omtaler pædagogisk designforskning som "an emerging paradigm for the study of learning in context through the systematic design and study of instructional strategies and tools" (2003, p. 5). Pædagogisk designforskning kan hermed defineres som: "A systematic but flexible methodology aimed to improve educational practices through iterative analysis, design, development, and implementation, based on collaboration among researchers and practitioners in real-world settings, and leading to contextuallysensitive design principles and theories" (Wang \& Hannafin, 2005, p. 6).

Forskningsmetoden har både fokus på at forbedre uddannelsespraksis og udvikle designprincipper og teorier for en ny praksis. Udgangspunktet for et pædagogisk designforskningsprojekt er konkrete praktiske problemstillinger, som indkredses, undersøges og forsøges løst. På grundlag af denne løsningsproces skaber metoden grundlag for systematisk vidensproduktion, der sigter mod at udvikle designprincipper og teorier. Forskningsmetodens kobling af praktisk aktion og systematisk undersøgelse viser, at pædagogisk designforskning er i familie med aktionsforskningens videnskabsteoretiske sigte om at ville forandre verden. Samtidig ligger der også et forståelsespotentiale i forandringsprocessen, således at der er et tæt samspil mellem forandring og forståelse, jf. "if you want to change something, you have to understand it, and if you want to understand something, you have to change it" (Gravemeijer \& Cobb, 2006, p. 45). Forskeren må engagere sig praktisk forandringsorienteret og bidrage til produktion af uddannelsens innovative former for at kunne erkende eller fortolke den sociale virkelighed. Omdrejningspunktet for forskningsprocessen er et designeksperiment. Et designeksperiment er den proces, hvori løsningen af en praktisk problemstilling udvikles, eksperimenteres med og undersøges med henblik på både praktisk problemløsning og systematisk teoriudvikling. Forskningsmetoden anlægger her et dobbeltmotiv på en pædagogisk problemstilling: På den ene side motivet om at løse problemstillingen set i en konkret pædagogisk kontekst og bidrage til at forbedre den pædagogiske praksis. På den anden side er motivet at udvikle ny viden, som kan ge- 
neraliseres på tværs af praksisformer og dermed bidrage til den pædagogiske forskning. Som Cobb et al. siger: "Design experiments are conducted to develop theories, not merely to empirically tune 'what works'” (2003, p. 9). Det forskningsmæssige dobbeltmotiv kan anskueliggøres i forhold til vores forskningscase:

- Problem: Hvordan kan Lektier Online udvikle og professionalisere deres uddannelse af lektievejledere og højne kvaliteten af lektievejlederens kompetencer?

- Praktisk pædagogisk mål: Hvilke metoder, modeller og materialer kan udvikle organisationen Lektier Onlines uddannelse af nye lektievejledere, herunder styrke lektievejledere i deres praktiske vejledning?

- Videnskabeligt pædagogisk mål: Hvordan kan en teori om lektievejledning og en lektievejledningsididaktik udvikles og beskrives?

Inden for designforskningstraditionen har man grundlæggede en fælles forståelse af forskningsmetodens mål: at forstå og forbedre undervisning og læring, men den metodiske vej til at organisere og strukturere forskningsprocessen hen mod dette mål er der forskellige bud på. Gravemeijer \& Cobb (2006) arbejder med en tre-faset-struktur: 1) forberedelse af eksperimentet i form af præcisering af et fagligt fokus og en undersøgelse af praksisfeltet, 2) eksperimenter i klasserummet og 3) retrospektive analyser. Fokus er på, hvordan forskeren, som er ekspert inden for et fagligt felt, kan udvikle, afprøve og konceptualisere fagdidaktiske teorier med læreren som en slags praktisk aktør i afprøvningen af de nye teorier. BannanRitland arbejder med en fire-faset model: 1) informeret undersøgelse, 2) afprøvning 3) evaluering af lokal effekt og 4) evaluering af generel effekt og videnspredning. Denne tilgang er inspireret af en ingeniørbaseret forskningstilgang med fokus på udvikling, test og spredning af uddannelsesmæssige innovationer, jf.: "How should we systematically create, test, and disseminate teaching and learning interventions that will have a maximum impact on practice and will contribute significantly to theory?" (Bannan-Ritland, 2003, p. 21). Reeves (2006) og Amiel \& Reeves (2008) arbejder ligeledes med en fire-feltmodel med faserne: 1) analyse af praktiske problemer, 2) udvikling af løsninger informeret af designprincipper og teknologiske innovationer, 3 ) iterativ cyklus af test og forbedringer af løsninger i praksis og 4) endelig refleksion over designprincipper og implementering af forbedrede løsninger (Reeves 2006, 96). Og endelig arbejder Gynther (2011) og Christensen et al. (2012) også med en fire-feltmodel: 1) kontekst, 2) lab, 3) intervention, 4) refleksion.

I nærværende projekt er vi inspireret af Amiel \& Reeves samt af Gynther og Christensen og deres fire-feltmodel som metodisk tilgang. En fusionering af disse to inspirationskilder følger i model 1 nedenfor. 
1. Undersøgelse

Problemidentificere og opbygge domænekundskab
2. Design

Udvikle nye innovative koncepter/prototyper

Pædagogisk

\section{Designforskning}

4. Generalisering

Forstå, evaluere og implementere koncepter
3. Intervention

Afprøve prototyper og dokumentere effekter

Model 1: Faser i Pædagogisk Designforskning

Modellen beskriver fire faser i arbejdet med en case. Første fase består i en undersøgelse af den eksisterende praksis og forskningslitteraturen på feltet med henblik på at opbygge teoretisk domænekendskab og afdække problemer og innovationspotentiale i casen. Denne fase rummer også en begyndende teoriudvikling i forhold til at indkredse, hvilke designeksperimenter, der kan arbejdes videre med i projektet. Praksis forstås her som en "learning ecology" (Cobb et al., 2003, p. 80; Gravemeijer \& Cobb, 2006). En læringsøkologi er et kompleks interaktionssystem, der består af forskellige elementer som opgaver, teknologier, lærerens kompetencer, undervisningsmetoder og undervisningssyn og klasserumskulturen. Det er disse elementers samspil, som tilsammen bidrager til at støtte de lærendes læreprocesser. Ovenfor eksemplificeres læringsøkologi til klasserummets interaktioner, men begrebet kan også gælde beskrivelsen af de interaktioner, som foregår i vejledningssituationer. Gennem undersøgelsen af lærings$\emptyset$ kologien undersøges det på den ene side, hvordan disse elementer samvirker, og på den anden side, hvordan denne læringsøkologi kan udvikles og forbedres.

Anden fase er designfasen, som ofte finder sted i et slags didaktisk værksted. Her samarbejder forskere og praktikere i en eller flere workshops for at udvikle og/eller teste løsningsforslag og nye prototyper, som kan håndtere problemer i den eksisterende praksis. Prototyperne er tentative bud på, hvordan problemer i praksis kan løses. Gravemeijer og Cobb taler om designforskeren som en bricoleur, der bruger alle de tilgængelige materialer i forhold til at udvikle nye koncepter: "A bricoleur is an experienced tinker/handy person, who uses as much as possible those materials that hap- 
pen to be available. To do so, many materials will have to be adapted; the bricoleur may even have to invent new applications, which differ from what the materials were designed for" (Gravemeijer \& Cobb, 2006, p. 51). Man kan i forlængelse heraf tale om pædagogisk designforskning som en 'metodisk bricolage', hvor designforskeren som en slags 'didaktisk innovatør' arbejder med at innovere og udvikle prototyper og nye koncepter ved at kombinere viden fra praksisobservationer, litteraturstudier, interviews med praktikere og kollaborativt samarbejde om udvikling og testning (se også Yee \& Bremner, 2011).

I tredje fase, intervention, bliver prototyper på de udviklede koncepter afprøvet i praksis med henblik på en undersøgelse af deres sociale robusthed og potentiale til at løse problemer i den pædagogiske praksis. I forbindelse med afprøvningerne af prototyperne lyttes der indgående til brugernes oplevelser og erfaringer, så det er muligt at justere eller redesigne det udviklede koncept.

Den fjerde fase er generaliseringsfasen, der handler om at undersøge og formidle prototypens praktiske brugbarhed og forskningsmæssige potentiale og på det grundlag generere ny teori. Der foregår i denne fase en retrospektiv analyse af designeksperimentet, hvilket Gravemeijer \& Cobb beskriver som en læreproces for forskerteamet: "Metaphorically speaking, the course of a design experiment can be characterized in terms of the learning process of the research team. We would argue that this learning process has to justify the products of the research project" (Gravemeijer \& Cobb, 2006, p. 75). I den retrospektive analyse undersøges, hvordan forskerteamet har arbejdet med designprocessen både for at skabe og validere den ny viden, dvs. undersøge, under hvilke vilkår de udviklede koncepter virker og hvilke læringsformer, de udmønter sig i. Målet er at sikre, at det nye koncepts har "økologisk validitet", dvs. "that results should provide a basis for adaptation to other situations" og fungere som "a frame of reference for teachers who want to adapt the corresponding instructional sequence to their own classrooms, and their personal objectives" (Gravemeijer \& Cobb, 2006, p. 77). Undersøgelsen af økologisk validitet bygger bl.a. på feedback fra undervisere, som har afprøvet de nye koncepter. Denne fjerde fase handler derfor også om at generalisere konceptet og muliggøre dets transformation til nye praksisser. Hvis konceptet er robust kan det implementeres i den eksisterende kontekst og her bidrage til innovativt at udvikle en ny praksis (jf. Gynther, 2011).

Modellens fire faser udgør en ramme og forskningsmetode for vores forskningsprojekt og forskningsaktiviteter:

1. Undersøgelse: interviewe uddannelsesansvarlige om hidtidig praksis i Lektier Online, undersøge eksisterende kursusmateriale og foretage litteraturstudier om lektiehjælp og vejledning i digitale miljøer. Målet er problemidentifikation og domænekendskab. 
2. Design: udvikle koncepter for uddannelse, vejledning og support gennem afholdelse af workshop kvalificeret af litteraturstudier af eksisterende uddannelseskoncepter og vejledningsteori. Målet er udvikling og kvalificering af designeksperimenter.

3. Intervention: følge et kursusforløb for nye lektievejledere med brug af nye koncepter. Målet er at finde ud om og hvordan designeksperimentet virker og evt. redesigne det.

4. Generalisering: evaluere koncepternes sociale robusthed og økologiske validitet samt formidle og udbrede deres potentialer til nye praksisser. Målet er at udbrede nye løsninger og generere ny generaliseret viden til andre kontekster.

Disse fire faser har struktureret vores udvikling af en vejledningsdidaktik omkring online lektievejledning og bruges i det følgende tillige som formidlingsramme til at kommunikere om processen i forskningsprojektets vidensproduktion.

\section{Fase 1. Undersøgelse, domænekendskab og pro- blemidentifikation}

Vores formål med afdækningen var at tilegne os viden om den hidtidige praksis og generelle udfordringer i Lektier Online, som var etableret både som organisation, uddannelse og digital lektiecafe. I afdækningsfasen foretog vi et individuelt forskningsinterview med syv projektmedarbejdere, der arbejder med Lektier Online for at fă en indsigt i medarbejdernes funktioner, ansvarsområder og baggrunde, samt deres holdning, viden, erfaringer og oplevelser af udfordringer med uddannelse af lektievejledere i Lektier Online. Dertil besøgte og observerede vi en aften i call-centeret på Statsbiblioteket, samt overværede et introduktionskursus for nye lektievejledere både i call-centeret, Statsbiblioteket og i call-centeret, Odense. Her fik vi indblik i, hvordan Lektier Online i praksis arbejder med uddannelse organiseret som præsentation af de nye kursister, introduktion til online lektiehjælp, diskussion af vejledningscases i workshop og simuleringsøvelser på den webbaserede kommunikationsplatform.

Afdækningen udmøntede sig i identifikationen af fem udfordringer for Lektier Online som lektie- og studiestøttekoncept:

1. Rekruttering (og fastholdelse). Hvordan kan Lektier Online rekruttere nye lektievejledere, og hvordan fastholde de eksisterende lektievejledere?

2. Uddannelse og kompetenceudvikling. Hvordan kan Lektier Online uddanne nye lektievejledere og kompetenceudvikle eksisterende lektievejledere?

3. Videndeling - fra tavs til eksplicit viden. Megen af den viden som opbygges om lektievejledning er bundet til den enkelte lektievejleder 
som rutiner og praksisser i form af "tavs viden". Udfordringen er, at arbejde med videndeling og omforme tavs viden til eksplicit viden.

4. Kvalitetssikring. Markedet for lektievejledning er stigende og Lektier Onlines vejledningsprodukt er også et produkt, som kommuner kan købe og abonnere på. Det er en kritisk opgave at beskrive, udvikle og fastholde kvalitet i Lektier Onlines ydelser.

5. Konceptualisering - franchise-modellen. Lektier Online er et koncept, som breder sig til flere universitetsbyer og det er en opgave at få konceptet til at fremstå ensartet og konceptualiseret.

Særligt uddannelsesopgaven, udfordring 2, var efterfølgende i fokus for vores forskningsprojekt. Lektier Onlines opgave med at uddanne nye lektiehjælpere kan siges at være særlig kompleks og udfordrende. Kompleksiteten ligger for det første i den generelle udfordring, det er at uddanne nogen til at håndtere en praksissituation som lektievejledning er. En vejledningssession er unik og kompleks, fordi eleverne er forskellige og de vil have forskellige udfordringer, der kræver en empatisk undersøgelse fra vejlederens side. En vejledningssituation kan ikke håndteres med en "teknisk rationalitet" (Schön, 2001) eller på forhånd givne metoder, fordi ingen metode "fits all". For det andet er der ikke udviklet teori og metoder om lektievejledning, der kan udgøre et velfunderet grundlag for uddannelse; lektievejledning er som vejledningsfelt et uopdyrket land. Spørgsmålet er, hvordan Lektier Onlines koncept for uddannelse kan bidrage til at engagere nye lektievejledere i det frivillige arbejde og fastholde deres interesse, socialisere dem ind i et fællesskab og Lektier Onlines værdier, og endelig kvalificere lektievejlederne til at udvikle vejledningskompetencer og løse deres vejledningsopgaver med en faglig og pædagogisk kvalitet? For at kunne svare på dette spørgsmål måtte vi opbygge domænekendskab om lektievejledning, vejledningsteori og vejledningsdidaktik.

\section{Domænekendskab - lektievejledning, vejledningsteori og vej- ledningsdidaktik}

Lektievejledning er en bred etableret praksis i skolesystemer både i Danmark og andre lande. Men det er ikke et etableret vejledningsområde teoretisk set og fremgår fx ikke af Lauvås og Handals (2006) oplistning af de fire centrale vejledningsområder:

- Erhvervsfaglig vejledning: vejledning i tilknytning til erhvervsvirksomhed eller uddannelse

- Opgavefaglig vejledning: vejledning i tilknytning til skrivning af opgaver inden for eller uden for en uddannelse

- Studie-/erhvervsvejledning: rådgivning til studerende om valg af uddannelse, fag, erhverv osv.

- Personlig vejledning/rådgivning: hjælp til kollegaer, studerende eller andre med personlige eller sociale problemer. 
I det følgende indkredses lektievejledning som vejledningsområde med udgangspunkt i en skandinavisk vejledningstradition. Der findes andre vejledningstraditioner, som kan understøtte udvikling af en vejledningsdidaktik, fx en angelsaksisk tradition, som bl.a. har fokus på at udvikle vejledning som pædagogisk praksis i videregående uddannelser (Godskesen \& Kobayashi, 2015; Lee \& Green, 2009; McAlpine \& Amundsen, 2009; Wisker, Robinson, Trafford, Warnes, \& Creighton, 2003). Vi har dog valgt at udvikle en lektievejledningsdidaktik, men udgangspunkt i en skandinavisk vejledningstradition, fordi denne tradition har et særligt blik for at sammentænke vejledning og didaktik (Inglar, 1999; Plant, Fogh-Nielsen, \& Hansen, 2011).

Traditionelt set kender vi den klassiske lektiehjælp først og fremmest fra hjemmene, hvor familien er i dialog med barnet om lektierne, alternativt konsulterer opslagsværker eller instruktionelle bøger. Gennem de senere år har dog både biblioteker, gymnasier og - indtil nyeste folkeskolelov, også folkeskoler etableret lektiecaféer efter skoletid, hvor elever med behov for hjælp, uformelt kan droppe ind på udvalgte tidspunkter (Gaardsted, Frausig, Poulsen, Frydendahl, \& Linton, 2007; Rasmussen, 2012). Tilbuddets mange fordele til trods har dog sine begrænsninger i forhold til både åbningstider, personalernes faglighed, ressourcer og geografiske afstande. Og med et tiltagende fokus på faglighed og karaktergennemsnit har også private lektiefirmaer konsolideret sig. Hvis man har behov for lektiehjælp, er det i dag ikke svært at google sig til et firma, hvor man kan købe sig til en privat lektiehjælper, der kommer hjem til én. Med teknologiens udvikling er der åbnet for yderligere nye tilgange til lektiehjælp, som en form for justin-time-teaching (Novak, Gavrini, Christian, \& Patterson, 1999). Eleven kan nu tilgå online lektiehjælp hjemmefra værelset via fx sin computer som en form for konsultativ interaktivitet (Jensen, 1998). Med kommercielle spillere som fx Khan Academy, Restudy.dk og Matematikfessor.dk kan eleven forberede sig til timerne på egen hånd ved at konsultere disse webbaserede fagportaler, der tilbyder ressourcer i form af små øvelsesfilm, tutorials eller opgaver. Men eleven kan også få hjælp til den specifikke opgave ved at logge på Lektieronline.dk, få kontakt til en lektievejleder og via direkte dialog blive guidet igennem lektieudfordringerne. Denne form er den eneste af sin slags i Danmark, men eksisterer eksempelvis også i fx Californien med www.tutor.com og www.brainfuse.com (Michaelson, 2009; Walter \& Mediavilla, 2005).

For at skabe overblik over lektievejledningens forskellige former har vi udviklet en model, som vi kalder 'Vejledningsformer' (model 2). Modellen er opbygget af to akser: tilgængelighed (on- og offline) samt vejledningsaktiviteter (konsultativ og dialogisk). Nedenfor ses en kortlægning af de forskellige lektiehjælps tilbud, som skole- og gymnasieelever kan gøre brug af. 


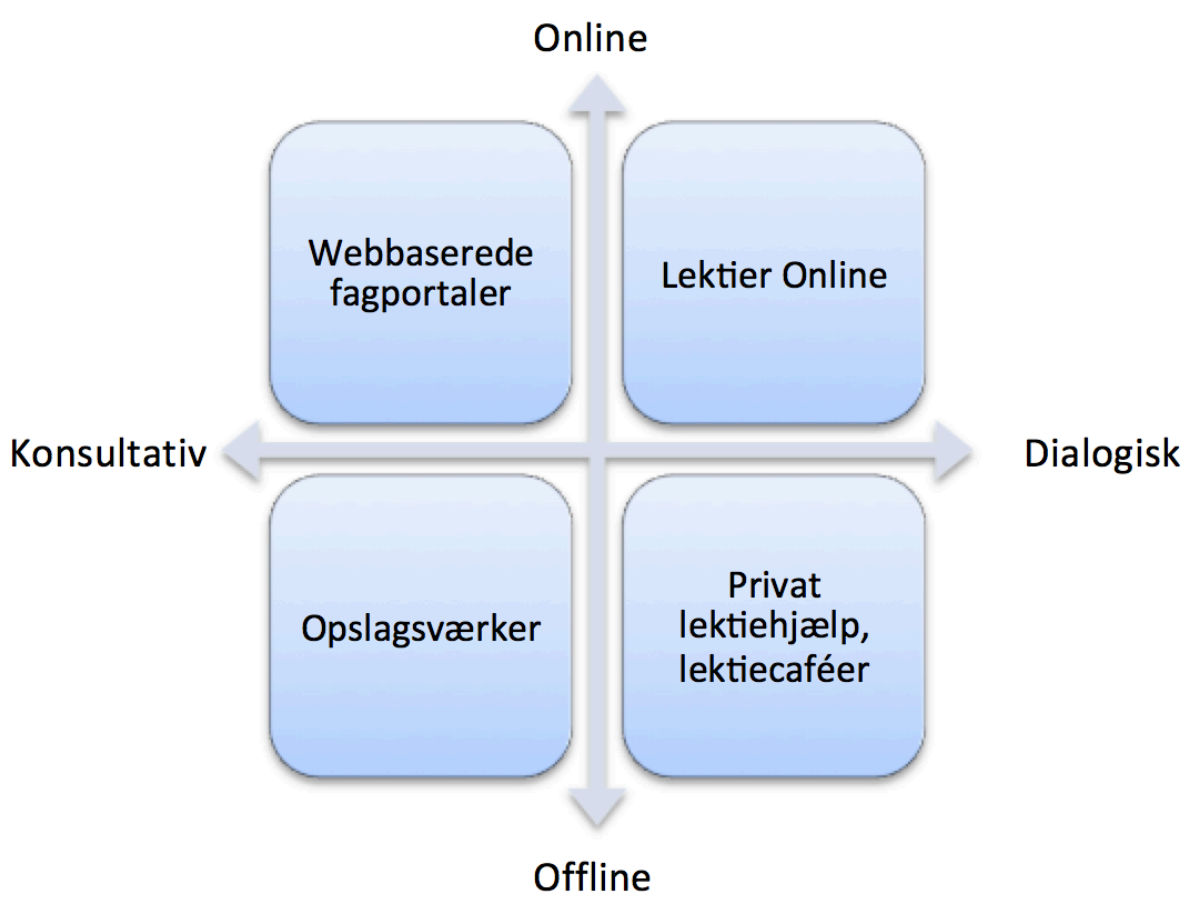

Model 2: Vejledningsformer

På baggrund af modellen kan man definere lektievejledning som en dialogisk eller konsultativ vejledning designet til at støtte elever i at foretage relevante valg i deres forståelse og løsning af skolerelaterede opgaver med det mål at styrke deres faglige handleberedskab og mod på læring. Lektier Online er del af den dialogiske, online lektievejledning og deres lektiehjælp kan karakteriseres som et online lektiehjælpstilbud for folkeskole- og gymnasieelever udført af frivillige universitetsstuderende situeret udenfor et formelt undervisningsrum. Det karakteristiske for den dialogisk lektievejledning er at dens formål er at støtte elevens løsning af opgaver og dermed styrke elevens faglige handleberedskab og mod på læring, som situation er et unikt møde, som indhold har elevens relation til fag, opgave og opgaveløsning og som metode fordrer reflekteret brug af vejledningsstrategier individuelt tilpasset elevens faglige udfordringer og forudsætningen.

Formålet med vejledningen er at styrke elevens individuelle handleberedskab. God lektievejledning handler ikke blot om mekanisk at applicere vejledningsmetoder, men lektievejlederen må på empatisk vis undersøge, hvad eleven ved, og hvad eleven ikke ved samt udvikle en fornemmelse for, hvad der virker afklarende og handlingsbefordrende for eleven, således at vejledningen bidrager til at åbne verden for eleven og giver mod på læring.

Vejledningssituationen er karakteriseret ved et unikt møde, der bør bygge på åbenhed og respekt for den vejledte og hans forudsætninger. Vejlederrollen fordrer en veludviklet relationskompetence forstået som: "vejlederens evne til at 'se' den vejledte på dennes præmisser og afstemme sin egen http://www.lom.dk 
adfærd efter det uden dermed at fralægge sig lederskabet i processer" (Nielsen, 2011, p. 21). Netop fokus på vejledning som graden af individuel tilpasning er det, der ifølge Inglar (1999) adskiller vejledning og undervisning, selvom man ikke kan drage et skarpt skel:

Når man kan tilrettelægge læringsaktiviteter for mange personer
samtidig på en måde, så de fleste har mulighed for at lære, kan vi
kalde det tilrettelæggelse af læringsaktiviteter. Det er det, der
sker, når man kender deltagernes læringsforudsætninger ret
godt, og når de, der skal lære, har samme mål. Når man forholder
sig til et enkelt eller et lille antal mennesker, kan man tilpasse sig
den enkelte og hjælpe den enkelte på en endnu bedre måde, og så
drejer det sig om vejledning. (Inglar, 1999, pp. 16-17).

Indholdet i en lektievejledningen kan ikke planlægges, men aktualiseres af den lærendes kommunikation om de udfordringer og problemstillinger, som han bringer med ind i en vejledningssituation. Indholdet består således i de mulighedsfelter, der ligger i den konkrete elevs relation til fag, opgaveforståelse og opgaveløsning. Vejlederrollen er karakteriseret ved, at man går ved siden af den lærende og forsøger at understøtte elevens læreprocesser, som det fremgår af Stålset, Sandal og Tventens (1994) definition på vejledning: "Å veilede et annet menneske innebærer at jeg må ta utgangspunkt i den andres indre bilde av virkeligheten, den andres mentale kart. All veiledning handler om tilrettelegging for læring, og læring handler om indre prosesser hos den som lærer" (Stålset, Sandal og Tventen, 1994, p. 51).

Vejlederen må her tilpasse sin vejledning til dette relationelle forhold og støtte den lærende $\mathrm{i}$ at forstå og håndtere den faglige udfordring samt identificere en vifte af muligheder, der giver mulighed for opgaveforståelse- og løsning og motivering af elevens indre læreprocesser. Lektievejleder er bogstavelig talt vej-leder og skal udpege mulige og motiverende ruter gennem landskabet af elevens konkrete faglige udfordringer.

Endelig skal lektievejledere reflekteret kunne benytte et bredt repertoire af vejledningsstrategier - og metoder, der kvalificeret hjælper eleven på vej. Den gode kvalificerede vejledning er ikke en "impulsiv rådgivning efter tilfældighedsprincippet", men består i et reflekteret og strategisk valg af vejledningsmetoder, hvor vejlederen er bevidst om "hvad man vælger at gøre, hvorfor man gør, og hvilke konsekvenser det kan medføre" (Inglar, 1999, p. 86).

Lektievejlederen står grundlæggende i sit eget "didaktiske felt" (Nielsen, 2011) og skal tage hurtige beslutninger om forståelse og handlinger i forhold til vejledningens didaktiske elementer: formål, situation, indhold og metoder. En vejledningsdidaktik skal her skærpe vejlederens forståelse af og refleksion om beslutninger i forhold til disse didaktiske elementer. 
Bogen "Vejledningsdidaktik" (Plant, Fogh-Nielsen, \& Hansen, 2011) beskriver generelt vejledningsdidaktik som "læren om vejledningsmetoder". I dette forskningsprojekt udvider vi denne definition og definerer vejledningsdidaktik orienteret mod lektievejledning, som de teorier og metoder, der kan støtte og vejlede en lektievejleder i forståelse af vejledningssituationens vilkår og problemstillinger i valg af vejledningsmetoder og i udmøntning af en individualiseret vejledning med det mål at styrke elevers faglige handleberedskab og mod på læring. En vejledningsdidaktik har således som mål at kvalificere en vejleder til reflekteret at forstå lektievejledningens formål, håndtere vejledningens situation og indhold og ved hjælp af metoder designe et forløb af vejledningsaktivitet samt etablere et refleksivt perspektiv på hele vejledningsprocessen. Designbegrebet refererer til "formgivning af den måde, hvorpå man som underviser/formidler direkte eller indirekte understøtter læring" (Hansen, 2012b, p. 56). I denne forståelse støtter en lektievejledningsdidaktik lektievejlederne i deres praktiske virkelighed og giver samtidigt et teoretisk blik på hele vejledningsopgaven og vejledningsprocessen ved at tilbyde et fagsprog, der sætter lektievejlederen i stand til at reflektere over og kvalificere sin egen vejledningspraksis.

\section{Fase 2. Design - udvikling af vejledningsmodeller}

På grundlag af arbejdet i undersøgelsesfasen udviklede vi fem modeller: Lektievejlederens logik, Kompetenceprofil for lektievejledere, Vejledningskompasset, Vejledningens scener og Vejledningsstrategimodellen. Disse modeller er for det første udviklet på grundlag af empiriske studier af den eksisterende læringsøkologi i Lektier Online. Vi har her observeret og deltaget i kurser for frivillige i både Århus og Odense, undersøgt eksisterende kursusmaterialer og observeret en række konkrete vejledningssessioner, hvor gymnasielever har fået konkret vejledning i call-centeret i Århus. For det andet har vi undersøgt den eksisterende litteratur om vejledning og som 'bricoleurs' udviklet fem modeller, som var vores bud på modeller, der kunne kvalificere og udvikle Lektiers Online koncept for uddannelse og lektievejledernes vejledningskompetencer. Vi præsenterer nedenfor de fem modeller. 


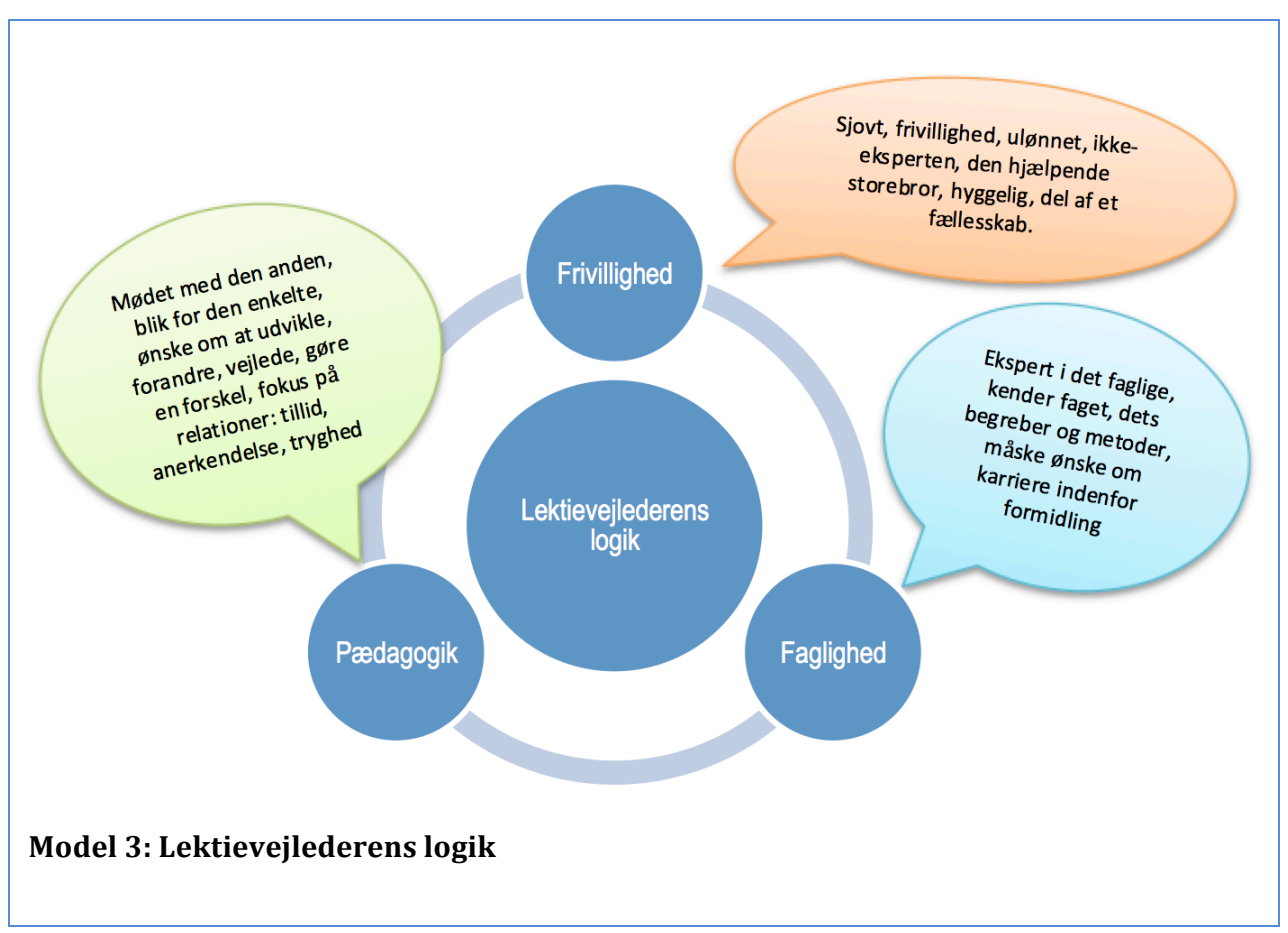

Modellen 'Lektievejlederens logik' er et bud på at indkredse de motiver, der driver en lektievejleder og hans grundlag for at blive lektievejleder. I vores observation af kurser for nye frivillige skulle de nye lektiehjælpere bl.a. præsentere sig selv og deres baggrund og interesse i at fungere som lektiehjælper. Her fandt vi, at lektievejlederens motivation befinder sig i et spændingsfelt af tre logikker: frivillighed, pædagogik og faglighed. Denne tredelte logik fandt vi efterfølgende bekræftet gennem litteraturstudier. Ifølge Barker (1993 i Anheier, 2005) er der tre grundlæggende motivationsfaktorer, der forklarer, hvorfor folk er frivillige: altruisme (omsorg og identifikation med de, der har brug for hjælp), instrumentalisme (tilegne sig nye erfaringer og kompetencer, møde nye folk og personlig tilfredsstillelse) og forpligtigelse (moral og ønske om bidrage eller politisk ønske om at forandre). Det altruistiske princip svarer her til den pædagogiske logik, det instrumentelle logik svarer til den faglige logik og det forpligtigende princip svarer til den frivillige logik. Modellen indkredser, hvad der karakterer de frivillige som målgruppe og kan dermed kvalificere Lektier Onlines strategi for rekruttering og planlægning af uddannelse. Frivillighed, som logik, er her et særligt aspekt, som man i Lektier Onlines uddannelseskoncept bør være opmærksom på. Det peger på, at der er en grænse for, hvor hårdt Lektier Online kan fare frem med krav om faglighed og pædagogik uden at miste lektievejlederens frivillige interesse og engagement. En frivillig lektiehjælper er en interessant aktør, fordi deres frivillighed er ulønnet og udspringer af en civil samfundskontekst, men de virker inden for en stærk politisk overvåget institutionel ramme, hvor lektiehjælp står højt på den uddannelsespolitiske dagsorden, og hvor der forventes en høj grad af faglighed fra lektiehjælperens arbejde. 


\begin{tabular}{|c|c|c|c|c|}
\hline $\begin{array}{l}\text { Kompetence- } \\
\text { profil }\end{array}$ & $\begin{array}{l}\text { Lektievejleder- } \\
\text { kompetence }\end{array}$ & Vejledning & Teknologi & Faglig kompetence \\
\hline Viden & $\begin{array}{l}\text { Kender } \\
\text { kompetenceprofilen } \\
\text { og Lektier Onlines } \\
\text { idegrundlag. }\end{array}$ & $\begin{array}{l}\text { Kender } \\
\text { vejledningens } \\
\text { scener og } \\
\text { vejledningsstrategi- } \\
\text { modellen. }\end{array}$ & $\begin{array}{l}\text { Kender L.O.-plat- } \\
\text { formens funktioner } \\
\text { og værktøjer. } \\
\text { Kender til online- } \\
\text { kommunikation. }\end{array}$ & $\begin{array}{l}\text { Har overblik over } \\
\text { sit/sine fag og } \\
\text { studiemetoder }\end{array}$ \\
\hline Færdigheder & $\begin{array}{l}\text { Deler erfaringer. } \\
\text { Er hjælpsom. } \\
\text { Støtter andre } \\
\text { lektievejledere som } \\
\text { mentor og } \\
\text { sparringspartner. }\end{array}$ & $\begin{array}{l}\text { Bruger vejlednings- } \\
\text { værktøjer. } \\
\text { Vejleder } \\
\text { differentieret }\end{array}$ & $\begin{array}{l}\text { Bruger funktionelt } \\
\text { L.O.-platformen. } \\
\text { Inddrager faglige } \\
\text { ressourcer og } \\
\text { værktøjer }\end{array}$ & $\begin{array}{l}\text { Kan finde relevante } \\
\text { faglige ressourcer. }\end{array}$ \\
\hline $\begin{array}{l}\text { Holdning/ } \\
\text { Væerdier }\end{array}$ & $\begin{array}{l}\text { Ser sig som del af } \\
\text { et fællesskab, der } \\
\text { bygger på sam- } \\
\text { arbejde, viden- } \\
\text { deling og gensidig } \\
\text { støtte. }\end{array}$ & $\begin{array}{l}\text { Sætter eleven i } \\
\text { centrum og har en } \\
\text { anerkendende og } \\
\text { empatisk tilgang. } \\
\text { Har fokus pă } \\
\text { elevens motivation } \\
\text { og mod på læring. }\end{array}$ & $\begin{array}{l}\text { Er interesseret i at } \\
\text { bruge teknologi og } \\
\text { holde sig opdateret. }\end{array}$ & $\begin{array}{l}\text { Forstăr sig selv som } \\
\text { faglig ressource- } \\
\text { person. }\end{array}$ \\
\hline
\end{tabular}

Model 4: Kompetenceprofil for lektievejledere

I Lektier Onlines eksisterende uddannelseskoncept var der ikke en eksplicit systematisk beskrivelse af, hvad en lektievejleder skal vide, kunne og på hvilket værdimæssigt grundlag. Kompetenceprofil for lektievejledere er en model, der vertikalt beskriver, hvilke kompetenceområder en lektievejleder skal fungere indenfor, og horisontalt udfoldes disse kompetenceområder i en taksonomi bestående af viden, færdigheder og holdninger/værdier (Hansen, 2012b). Kompetenceområderne omfatter vertikalt fire typer kompetencer:

- Lektievejlederkompetence - en overordnet kompetence som lektievejleder og repræsentant for Lektier Online.

- Vejledningskompetence - kompetence til at vejlede andre.

- Teknologikompetence - kompetence til at håndtere vejledningsplatformen og online vejledning.

- Faglig kompetence - kompetence i det faglige område.

Kompetencetaksonomien omfatter hertil tre horisontale niveauer af kompetence:

- Viden - hvad skal en lektievejleder vide i forhold til den enkelte kompetence.

- Færdigheder - hvad skal en lektievejleder kunne i forhold til den enkelte kompetence.

- Holdninger/værdier - hvilke holdninger/værdier skal en lektievejleder udvikle/besidde i forhold til den enkelte kompetence.

I forskningslitteraturen taler man om tre typer vejledningskompetencer: færdigheder, generative kompetencer og holistiske kompetencer (C. R. P. 
Bjørndal, 2011). Færdigheder er fx samtalefærdigheder og færdigheder i at organisere og kommunikere med andre mennesker: kontakt, anvendelse af vejledningsmodeller, aktiv lytning, spørgsmålsteknik og metakommunikation. Generiske kompetencer omfatter generelle kompetencer, som kan overføres fra situation til situation, fx evne til empati, problemløsning, selvstændighed og samarbejde. Holistiske kompetencer viser sig ved, at vejlederen tager hensyn til vejledningskonteksten og har fokus på det dynamiske samspil mellem aktører, handlinger og vejledningskonteksten. I vores model kan man karakterisere 'lektievejlederkompetencen' som en holistisk kompetence, og de tre øvrige kompetenceområder: vejledningskompetence, teknologikompetence og faglig kompetence som mere færdighedsorienterede og generiske kompetencer.

Kompetenceprofilen har som funktion at formidle lektievejlederuddannelsens mål og indhold til nye lektievejledere og skærpe forståelsen af lektievejlederens kompetencer for eksisterende lektievejledere. Potentialet $\mathrm{i}$ modellen er, at den muliggør en klar kommunikation til kommende lektievejledere om, hvad det indebærer at være lektievejleder for at sikre forståelse og engagement om, hvad uddannelsen går ud. Endvidere sikrer modellen et grundlag for intern kommunikation om lektievejlederens kompetence samt justering og udvikling af disse kompetencer.

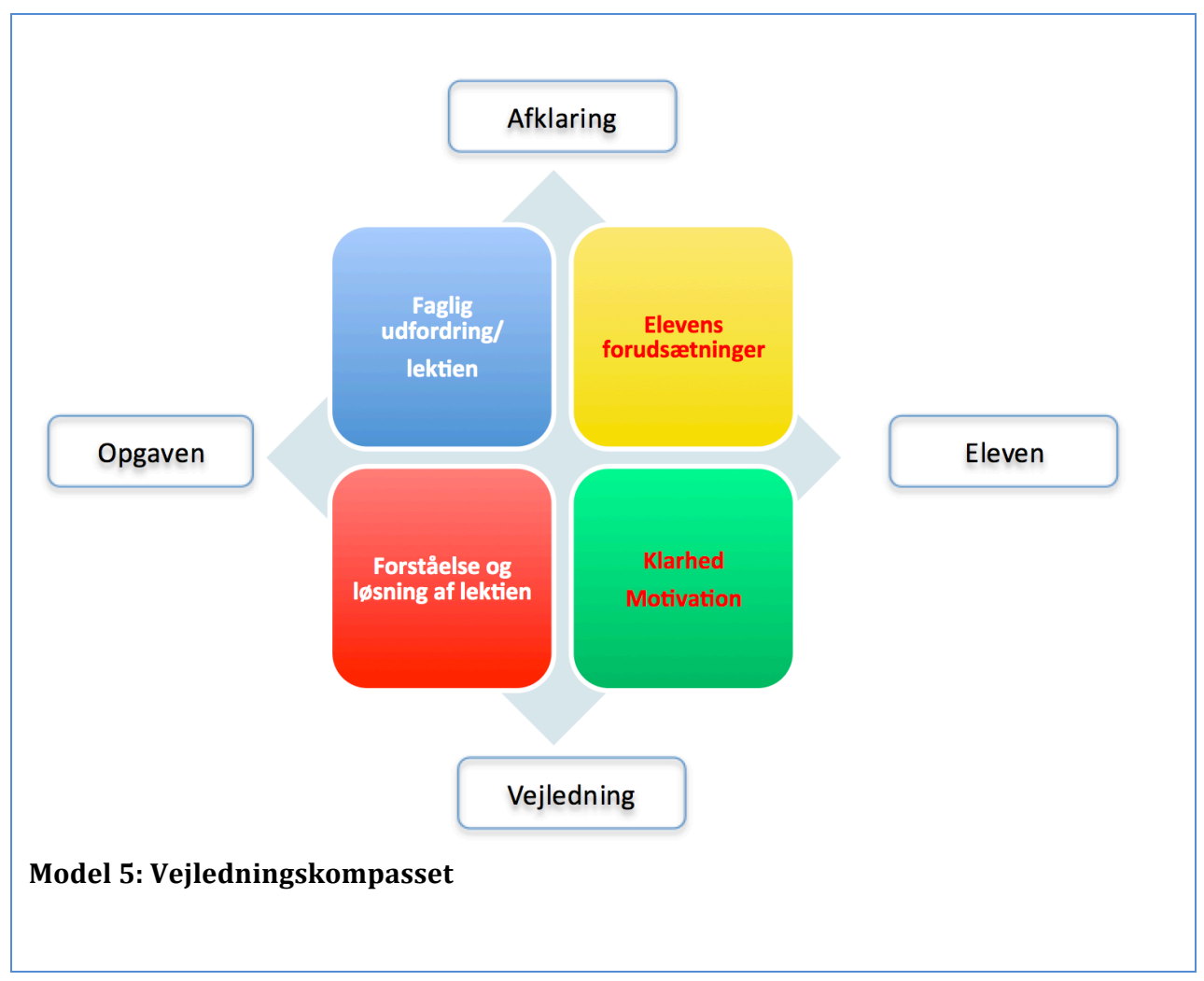


Vejledningskompasset er en model, der udpeger fire forskellige vejledningsopgaver, som generelt karakteriserer lektievejlederens arbejde i en vejledningssituation. Modellen tager udgangspunkt i, at lektievejledning er en kommunikationsform, der har til hensigt at hjælpe, støtte og stilladsere en anden i dennes læring og udvikling af motivation og mod på læring. Modellen peger på, at en vejledningssituation er spændt ud mellem en afklaringsdimension - hvad er opgaven og hvem er eleven? - og en vejledningsdimension - hvordan vejledes eleven i at forstå og løse lektien, og hvordan muliggøres elevens klarhed over det videre arbejde og motivation for læring? Afklaringsdimensionen handler om, at lektievejlederen må "tage udgangspunkt i den anden (den vejledtes) indre billede af virkeligheden" (jf. Stålsett et al. ovenfor) og her få et indtryk af den lærendes forudsætninger og umiddelbare læringsstrategier i forhold til at løse opgaven. Vejledningsdimensionen bygger på en række vejledningsmetoder og spørgsmålstyper, som skal muliggøre, at eleven kan forstå og håndtere sin lektie, hvilket uddybes i Vejledningsstrategi-modellen.

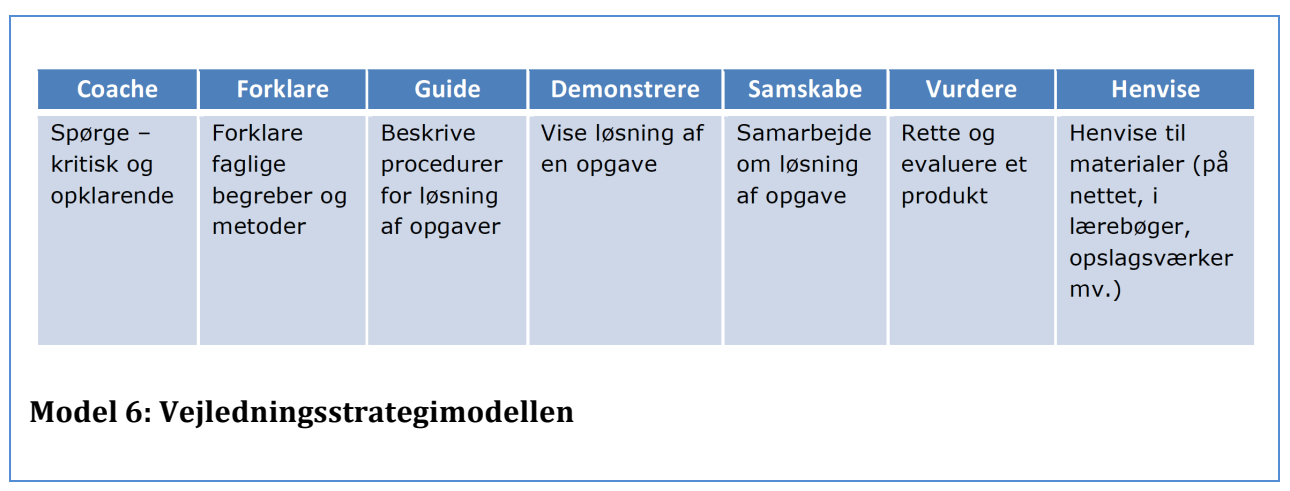

Vejledningsstrategimodellen beskriver et repertoire af vejledningsmetoder, som lektievejledere kan benytte som grundlag for sin vejledning, og hvis sammensætning afspejler lektievejlederens plan for vejledning. Formålet med Vejledningsstrategimodellen er - med udgangspunkt i en forståelse af elevens vejledningsbehov, opgavens karakter og elevens faglige forudsætninger - at skærpe lektievejlederens plan med vejledningen og refleksion over, hvordan der kan vejledes, herunder valg og sammensætning af en række vejledningsmetoder:

- Coache - handler om kritisk og opklarende at spørge ind til elevens forståelse af opgaven, og hvordan eleven kunne forestille sig at løse opgaven. Typisk kommunikation: "Hvordan forstår du opgaveformuleringen?", "Hvordan forestiller du dig at løse opgaven?".

- Forklare - lektievejlederen forklarer noget, fx hvordan opgaven skal forstås, hvordan man skal forstå bestemte faglige begreber, eller hvordan man konkret arbejder med en bestemt faglig metode. Typisk kommunikation: "En analyse af kunsteventyrets genrer vil sige at du 
skal...", "Et kunsteventyr har typisk følgende genretræk...", "En tekstanalyse kan besvares i følgende faser..."

- Guide - lektievejlederen guider eleven gennem en procedure, typisk en procedure for, hvordan eleven kan løse en opgave. Typisk kommunikation: "Når du skal lave dit projekt, skal du skal skelne mellem redegørelse, analyse og diskussion..."

- Demonstrere - lektievejlederen demonstrerer, hvordan eleven løser en opgave, ofte i en situation, hvor eleven har flere opgaver at løse. Herefter arbejder eleven selv med at løse de øvrige opgaver. Typisk kommunikation: "Nu viser jeg, hvordan du regner den første opgave...", "Nu viser jeg dig, hvordan man kan søge på nettet..."

- Samskabe - lektievejlederen arbejder sammen med eleven om at løse en opgave. Den vejledningsmetode kan benyttes i de situationer, hvor eleven er virkelig fagligt udfordret, og hvor andre vejledningsmetoder ikke synes brugbare. Typisk kommunikation: "Først skal vi finde noget information om kunsteventyret. Hvordan gør vi det?..."

- Vurdere - lektievejlederen har rollen som evaluator af et produkt, det kan være tjek af formelle fejl eller en vurdering af procedurer for opgaveløsning. Typisk kommunikation: "Du har brug for at tjekke opgaven for kommatering. Jeg tjekker den første del, og så taler vi om reglerne for kommatering."

- Henvise - lektievejlederen henviser eleven til yderligere materialer (på nettet, i opslagsværker og lærebøger mv.), som kan styrke elevens løsning af opgaven. Typisk kommunikation: "Du kan finde mere litteratur om projektopgaven på disse sider..."

Vejledningsmetoderne er fænomenologisk udviklet på grundlag af vores observation af den eksisterende vejledningspraksis i Lektier Online. Men det teoretiske belæg for de syv metoder kan også findes i Inglars beskrivelse af fire vejledningsstrategier (1999): Den formidlingsorienterede vejledning, hvor vejledning er en overføring af vejlederens erfaringer og værdier. Ofte stilles ikke spørgsmål, og vejlederen vil til den vejledtes beskrivelse svare med "Ja, det er godt, men jeg synes hellere du burde...". Den procesorienterede vejledningsstrategi, hvor vejledning er en lyttende og udforskende proces centreret om den vejledtes nærmeste udviklingszone og med fokus på, at den vejledte selv konstruerer sin opgave. Den konfluente (gestalt)orienterede vejledning, hvor vejlederens opgave er, at tilrettelægge situationer, hvor den vejledte selv kan reflektere og opdage. Den kritisk orienterede vejledning, hvor vejlederen har en analyserende og problematiserende indstilling og vil være optaget af, at drive den vejledte frem til videre analytisk tænkning om sin situation "Hvorfor har du...?", "Hvorfor anvender du netop denne metode?", "hvad ville det betyde for din løsning af opgaven, hvis du brugte en anden teori?".

Grundlaget for vejledningsstrategimodellen er pragmatisk, fordi vi har kunnet observere, at en vejledningssession består af en kombination af de 
ovenstående vejledningsmetoder. Valg, sammensætning og brug af vejledningsmetoder er en kompetence, som grundlæggende bygger på lektievejlederens situative dømmekraft i forhold til vejledningssituationen, elevens vejledningsbehov, vejledningens tidsmæssige omfang og mål for vejledningen. Mål for vejledningen kan fx være, om eleven skal forstå en opgave, tilegne sig faglige begreber og metoder, forstå proceduren for løsning af en opgaven, har brug for en demonstration af en arbejdsmåde, har brug for tæt samarbejde om løsning af en opgave, har brug for et tjek af et produkts kvalitet eller har brug for yderligere perspektiver på arbejdet med en opgave.

\begin{tabular}{|c|c|c|}
\hline Flow & $\begin{array}{l}\text { Frontstage } \\
\text { (den synlige kommunikation) }\end{array}$ & $\begin{array}{l}\text { Backstage } \\
\text { (den usynlige refleksion) }\end{array}$ \\
\hline $\begin{array}{l}\text { Velkomst og } \\
\text { præsentation }\end{array}$ & Gensidig præsentation & $\begin{array}{l}\text { Vær opmærksom på dobbeltfunktion som } \\
\text { faglig autoritet og uformel "ven" }\end{array}$ \\
\hline Afklaring & $\begin{array}{l}\text { Form for kommunikation } \\
\text { Afstem forventninger } \\
\text { Elevens "problem" - lad eleven } \\
\text { læse/vise problem + forklare med } \\
\text { egne ord } \\
\text { Rammesætning af tid og roller }\end{array}$ & $\begin{array}{l}\text { Hvad er elevens forudsætninger (faglig og } \\
\text { sprogligt)? } \\
\text { Hvad er elevens faglige udfordring/opgave? } \\
\text { Hvilken vejledningsstrategi skal benyttes? }\end{array}$ \\
\hline Vejledning & $\begin{array}{l}\text { Vejledningsmetoder: Coache, Forklare, } \\
\text { Guide, Demonstrere, Samskabe, } \\
\text { Vurdere, Henvise }\end{array}$ & $\begin{array}{l}\text { Vejledningssituation - løsning af opgaven } \\
\text { Udviklingsdimension - mod på læring }\end{array}$ \\
\hline $\begin{array}{l}\text { Opsummer \& } \\
\text { afslut }\end{array}$ & $\begin{array}{l}\text { Evaluering: } \\
\text { Fik eleven den ønskede hjælp? } \\
\text { Farvel og inviter til at komme tilbage }\end{array}$ & $\begin{array}{l}\text { Refleksion: } \\
\text { Hvordan gik det, hvad gik godt og hvorfor? } \\
\text { Hvad skal jeg overveje til næste gang? }\end{array}$ \\
\hline odel 7: Vej & dningens scener & \\
\hline
\end{tabular}

Vejledningens scener er en model, der for det første viser, at flowet i et vejledningsforløb ofte er struktureret i fire faser: Velkomst, Afklaring, Vejledning, Opsummering med afslutning. For det andet viser modellen, hvordan der til hver fase er knyttet en synlig kommunikation (frontstage) og en usynlig refleksion (backstage). Modellens formål er at understøtte lektievejlederens synlige kommunikation og de kommunikative opgaver, der er knyttet til den eksplicitte vejledning, samt lektievejlederens usynlige refleksion, som kvalificerer lektievejlederens strategiske arbejde med afklaringsdimensionen og vejledningsdimensionen (jf. Vejledningskompasset).

\section{Udvikling og test af vejledningsmodeller}

De ovenstående fem modeller er blevet præsenteret, videreudviklet og testet i samarbejde med forskellige grupper af involverede interessenter i Lektier Online for at sikre modellernes økologiske validitet. Vi identificerede følgende tre interessentgrupper, som med deres erfaringer fra praksis ville være relevante at inddrage i udviklingsprocessen: 
1. De uddannelsesansvarlige: Statsbibliotekets gruppe af projektmedarbejdere og strategiske medarbejdere, der arbejder med Lektier Online

2. Netværksgruppen: Gymnasielærere og administrative ansvarlige fra de gymnasier, der er tilknyttet Lektier Online

3. "Flyverne": Lektievejledere, der er ansat af Lektier Online som tovholdere for de frivillige.

På Statsbiblioteket afholdt vi en workshop for hver af de tre grupper. Antallet af deltagere var mellem 5 og 8 pr. gang. Formålet med workshopperne var, at vi, ved at inddrage de tre interessentgrupper én efter én i udviklingsprocessen, kunne skabe rum for kollaborativt at tilvejebringe forskningsdata, der yderligere kunne validere og kvalificere de fem modeller. Der var således tale om skabe en ramme for en form for praksisfællesskab (Wenger, 1998), hvor vi i samarbejde med praksisfeltet kunne generere viden. Workshopmetoden er inden for brugerinddrevet innovation en central teknik, der kan bruges i forbindelse med udvikling, evaluering og verificering af konkrete designs (Bødker, Kensing, \& Simonsen, 2008). Metoden kan betragtes som nært beslægtet med fokusgruppe interviews, hvor en moderator introducerer et emne for diskussion og herefter faciliterer diskussionen (Kvale, 2007). Begge er kvalitative metoder, og ligheden ses desuden i moderatorens/workshoplederens opgave i at skabe rum for deltagernes betragtninger. Men hvor fokusgruppeinterviewet er en organisering af en mundtlig session, der skal optages og sidenhen transskriberes, så er workshopmetoden mere aktiverende, hvor andre udtryksformer kan bringes i spil.

I forberedelsen af workshoppene var fokus var på at stille spørgsmål og i den forbindelse tilrettelægge aktiviteter, som kunne give os nogle svar på de problematikker, vi havde identificeret - samt give os indsigt i de områder, som vi i projektet havde brug for oplysninger om. I tilrettelæggelsen af workshoppene var vi opmærksomme på, at sætte nogle rammer, så vi kunne få skabt noget data, vi kunne tage med videre.

For alle tre workshops var den overordnede form en vekselvirkning mellem præsentation og aktivitet, hvor modellerne først blev introduceret og herefter udlagt til refleksion, diskussion, vurdering og kommentering. Aktiviteterne var ikke nødvendigvis tiltænkt et specifikt læringsmål, men udelukkende designet for, at vi som forskere i projektet kunne skabe et rum, hvor deltagernes perspektiver kunne komme til udtryk - nogle gange som individuelle refleksioner, andre gange diskuteret og forhandlet i dialog med en gruppe eller makker. 
Til aktiviteterne anvendte vi især opgaver, hvor deltagerne noterede deres bidrag på post-its i forskellige farver, og i lokalet blev hvide posters med opgavernes overskrifter hængt op, som post-its'ne herefter kunne placeres på. Det fysiske artefakt ophængt i rummet bidrog til, at deltagerne hele tiden kunne orientere sig om den indsamling, der fandt sted, og dermed havde man også mulighed for at vende tilbage til noget, hvis der i processen dukkede nye idéer op. De udfyldte postere endte med at blive til dokumentation for den dataindsamling, der havde fundet sted.

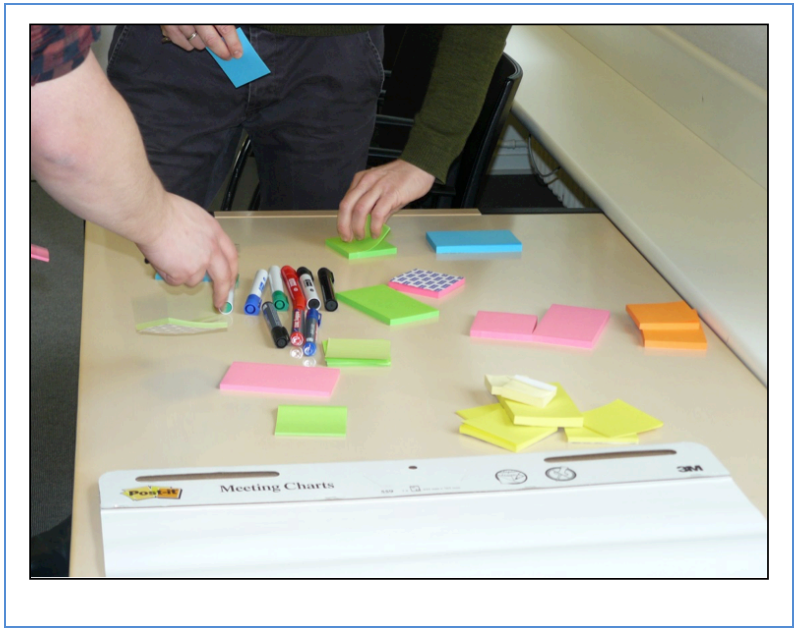

Ved post-it-sessionerne skulle farverne i en aktivitet $\mathrm{fx}$ svare til det enkelte spørgsmål: Hvad skal en lektievejleder vide? Hvad skal en lektievejleder kunne? Hvilke værdier skal en lektievejleder have med? I andre aktiviteter skulle farverne symbolisere den grad af opmærksomhed, som deltageren synes de enkelte bidrag skulle have (fx Grøn = Virker, Gul= Forbedres, Rød = Virker ikke). Alle aktiviteter blev afsluttet med en plenumgennemgang, dels for at deltagerne kunne sætte ord på deres bidrag til os andre, dels for at give plads til yderligere refleksion og eventuelle bidrag. Disse plenumsessioner blev lydoptaget, så vi havde mulighed for at være til stede i dialogen og ikke være afhængige af at skulle skrive noter samtidigt.

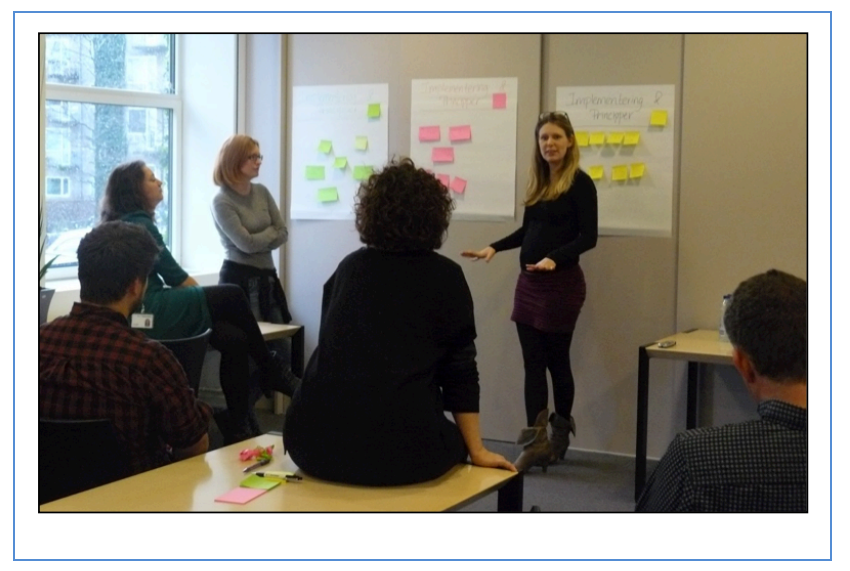

I den første workshop var enkelte aktiviteter tilrettelagt individuelt for at give plads til den enkeltes refleksion, men det viste sig at være for tidskrævende at samle op på det i plenum, og vi ønskede en højere grad af dialog mellem deltagerne, hvorfor vi fremadrettet hovedsagligt lagde op til grupper af 2-3, så de havde mu-

lighed for at spare med og lade sig inspirere af hinanden. Hvis vi stillede opgaver, hvor vi forventede en større mængde af skriftlige refleksioner, benyttede vi os af en virtuel opslagstavle i form af padlets (padlet.com), hvor opgaverne 
kunne besvares. Padlet-værktøjet egnede sig især godt til at opsamle og præsentere de forskellige gruppers bidrag.

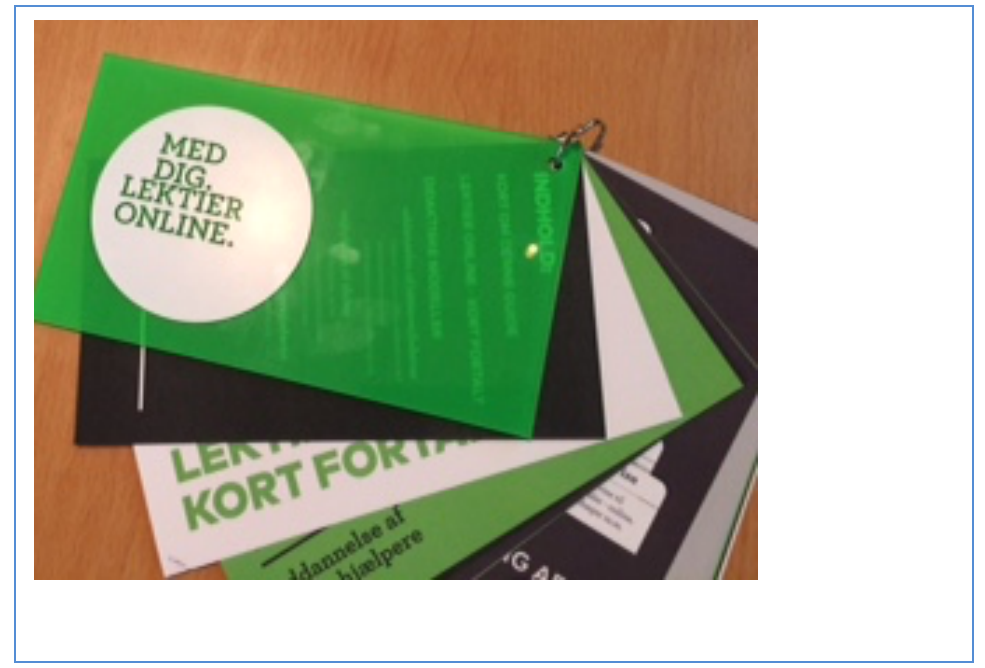

Efter design-fasen med flere iterationer af de fem modeller blev en prototype på en "Lektier Online Håndbog" produceret, hvor de fem modeller er præsenteret. Håndbogen indgår som kursusmateriale i uddannelsen af nye lektiehjælpere og som en guide i forhold til håndtering af vejledningssessionerne i et call-centre.

\section{Fase 3 - Intervention}

I interventionsfasen er håndbogen med de fem modeller afprøvet og sat i spil på tre kurser i efteråret 2015. Vi deltog som forskere på et af disse kurser, hvor 9 frivillige deltog. Kurset begyndte med en præsentation af de frivillige og et oplæg af kursusholderen, der introducerede til Lektier Online og de fem vejledningsmodeller. Herefter blev der organiseret en faglig workshop, hvor kursisterne i to grupper trak en vejledningscase, som de i diskussion med hinanden skulle komme med et bud på vejledning af. I deres diskussion var opgaven at benytte de fem vejledningsmodeller, især 'Vejledningsstrategi-modellen'. Kurset sluttede af med et besøg i callcentrets it-lokale, hvor kursisterne blev præsenteret for lektievejledningsplatformen og i grupper af to simulerede en lektievejledning, hvor de også havde håndbogen og de fem modeller til rådighed.

Alle tre kurser sluttede af med at kursisterne evaluerede de fem modeller i form af en spørgeskemaundersøgelse. Undersøgelsens formål var at evaluere kursets overordnede kvalitet og specifikt vejledningsmodellernes usability (Benyon, 2013, p. 81), forstået som modellernes forståelighed (lette at lære og forstå) og brugsværdi (effektive i forhold til at løse praktiske opgaver). Surveyen var opdelt i to dele: Først en generel del om kurset, hvor der blev spurgt ind til de studerendes oplevelse af kurset. Herefter en del, hvor fokus var på fire af de fem modeller 1) Kompetenceprofil for lektievejledere, 2) Vejledningskompasset, 3) Vejledningens scener samt 4) 
Vejledningsstrategimodellen. Her blev de studerende spurgt ind til anvendeligheden af modellerne.

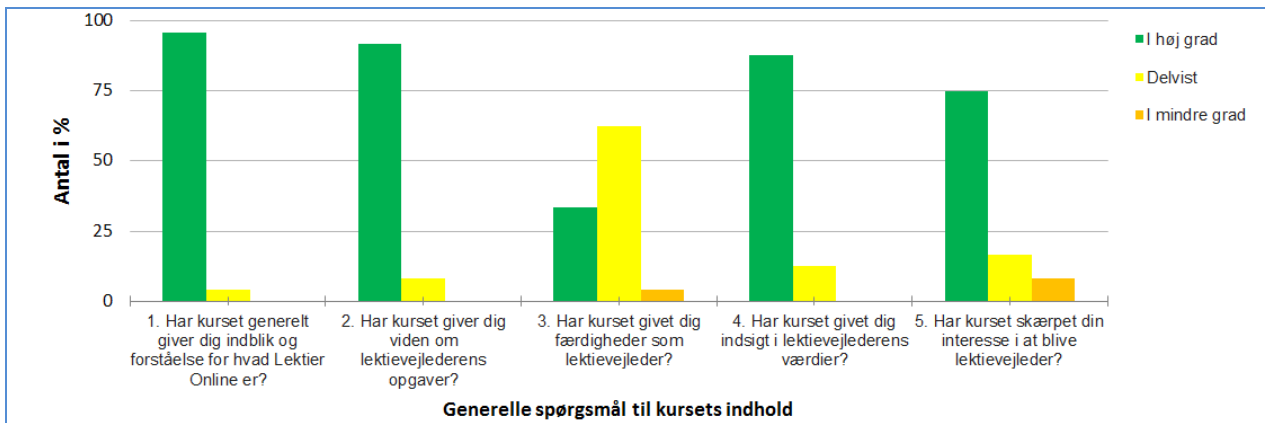

Tabel 1: Deltagernes generelle oplevelse af kurset

I alt 24 studerende besvarede surveyen, og ud fra besvarelserne ses det, at der generelt set var en overordnet tilfredshed med kurset. En del af de studerende fremhæver bl.a. den generelle introduktion, de praktiske øvelser og vejledningsmodellerne som en positiv oplevelse:

Det var virkelig betryggende, at kurset begyndte med en introduktion og forklaring af hvad "Lektier Online" består af. Derefter blev vi sat i grupper og kunne tale om det vi lige havde hørt, på den måde fik jeg det teoretiske på plads og følte at jeg havde fået en konkret forståelse af "Lektier Online". Det fungerede så fint med den naturlige overgang til det praktiske aspekt, hvor man både var elev og lektiehjælper. Jeg syntes at kurset har været ekstremt godt, jeg har virkelig fået meget ud af de her timer. (Kursist).

Den generelle introduktion. Opdelingen af tilmeldte efter hvad de ville undervise i. Det var også rart, at det blev gjort i et langt stræk, fordi man ligesom bliver introduceret fortløbende, og at vi får lov at applicere det, vi har beskæftiget os med teoretisk. Desuden giver de DIDAKTISKE MODELLER [vejledningsmodellerne] et godt indblik i, hvilke situationer man kan komme ud for, og hvordan man skal håndtere dem. (Kursist).

Når 15 af kursisterne $(62,5 \%)$ ved spørgsmål 3 tilkendegiver, at kurset kun delvist har givet dem de fornødne færdigheder, kan det tolkes som, at kursisterne kan have svært ved at gennemskue, om de færdighedsmæssigt har opnået de nødvendige kompetencer, da de ikke har prøvet en reel vejledningssession endnu. Følgende kommentarer understøtter dette: "Jeg synes det var lidt svært at fornemme hvordan det egentlig vil være at snakke med 
en elev i stedet for en anden person til stede på introkursuset" (Kursist), og "Jeg tror det er learning by doing herfra :)" (Kursist).

Desuden efterlyses det, at der var mere tid til at træne med de cases, som blev lagt frem på kurset: "Mere tid til prøvesessionerne. Med lidt tekniske problemer og siden det er første gang, så oplevede jeg, at man ikke fik særlig meget tid til at prøve en rigtig session af" (Kursist).

Der savnes ikke noget på kurset andet end måske lige nogen rigtige elever at arbejde med: "Jeg synes faktisk ikke, at der manglede noget. Det er selvfølgelig synd, at man ikke kunne prøve på rigtige elever, men det kan man heller ikke forvente. :)" (Kursist).

Tilbagemeldingerne på de fire vejledningsmodeller ser vi ligeledes som positive.

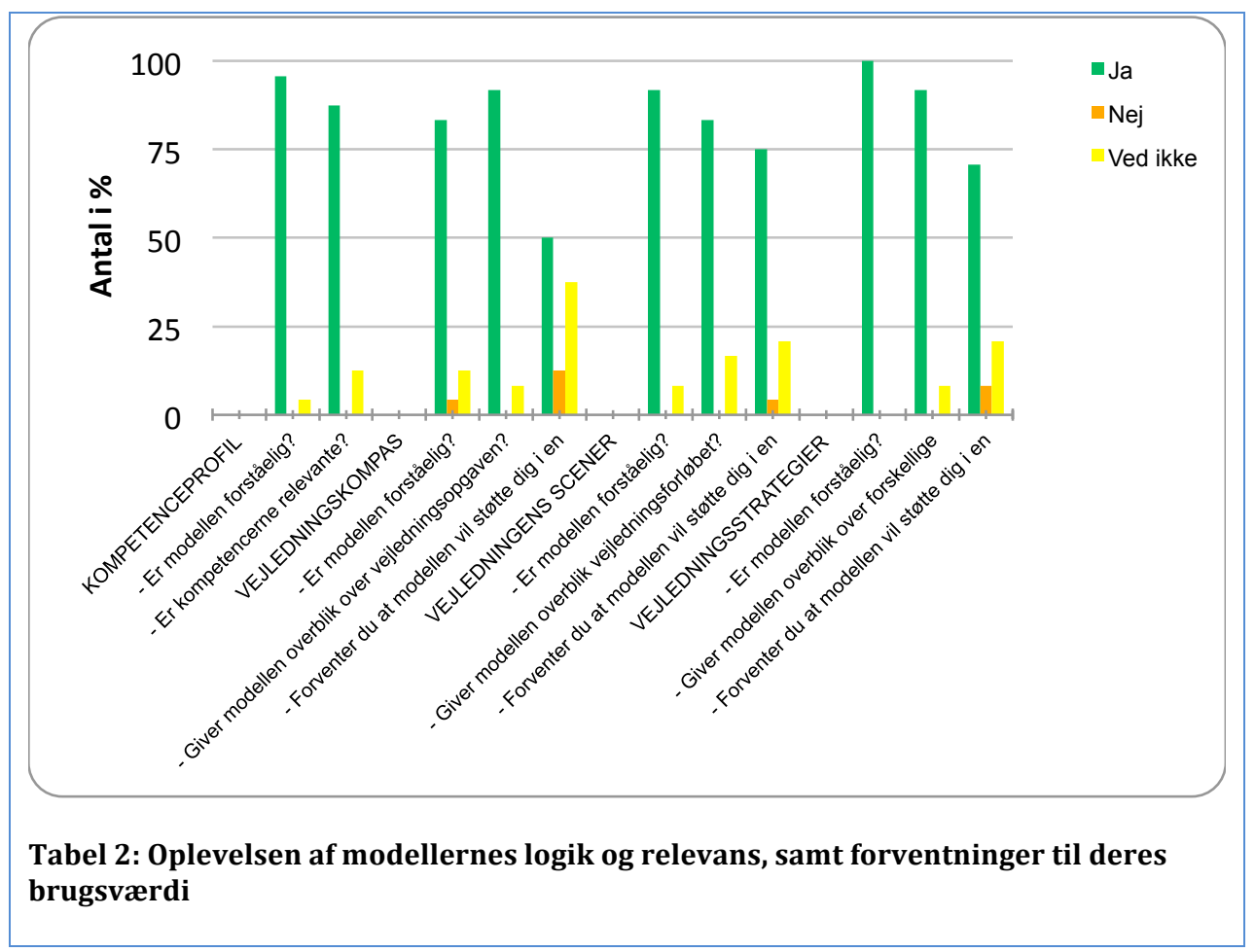

Tabel 2 viser, at kursisterne vurderer de fire modeller som forståelige, relevante, og at de kan bidrage til at skabe overblik i forbindelse med lektievejledningens forskellige facetter.

Det er således i forhold til modellernes forståelighed nogle meget positive evalueringer. Hvad angår overblik og forventninger til modellernes praktiske brugsværdi i selve vejledningssituationen, har nogle af de studerende lidt svært ved at forestille sig praksis som lektiehjælper, og kvier sig derfor ved at tage stilling til modellernes funktion i praksis. Et par studerende http://www.lom.dk 
giver udtryk for, at de vil kunne give et mere nuanceret svar, når de har prøvet at have nogle sessioner som lektiehjælper: "Jeg synes, at kurset har været godt, men det er svært at vide nu, om der er kompetencer, jeg mangler. Måske en opfølgning efter et par måneder?" (Kursist).

De to kursusafholdere blev også interviewet om de fem modeller og det nye koncept for uddannelse af lektievejleder. Evalueringen havde her som formål at evaluere deres oplevelse af modellerne anvendelighed som del af deres kursusforløb og som bidrag til at udvikle lektievejledernes vejledningskompetencer. Den ene af kursusafholderen siger:

Nu har jeg læst kursusmaterialet inden, og jeg synes det var meget præcis udformet med de ting, som vi gør i de situationer, når vi vejleder, som vi ikke tænker over, fordi det fungerer som en automatisk proces og selv om det virker som en lidt søgt proces, at man skal bladre rundt så gav det en enorm god forståelse for, hvad du gør i situationen, og det så ud som om lektiehjælperen fik en klarere forestilling om, hvad forløbet i en session er, og hvad man skal være obs på. (Kursusafholder 1 ).

Her fremhæves modellernes funktion som spejl af en lektievejlederes praksis og som redskab til at reflektere over, hvad der er spil i en vejledningssituation. Modellerne bidrager til at udvikle lektievejlederens fagsprog om egen praksis, hvilket den anden kursusafholder også pointerer: "Det, som er rigtig godt med de modeller, er at der bliver sat ord på de ting, man egentlig gør - mange ting vil man gøre ubevidst - men nu får man ligesom et begrebsapparat" (Kursusafholder 2).

Kursusafholdernes vurdering afspejler også modellernes sociale robusthed. Modellernes potentiale i forhold til at tilbyde et fagsprog om lektievejlederens praksis kan perspektiveres i lyset af Dales (1998) teori om professionskompetencer, jf. ovenfor. Dale hævder, at der bør være en indre relation mellem kompetenceniveauerne k1, k2 og k3, og det kan ske: "[...] når disciplinens grundbegreber, principper og kriterier indgår problemorienteret og analytisk som referenceramme i lærerens handlingsrefleksion. Relationen mellem at planlægge, gennemføre og vurdere undervisning legitimeres i forhold til grundlæggende og dækkende teorier. Vellykket efteruddannelse omstrukturerer lærernes referencerammer" (Dale, 1998, pp. 224-225).

Vejledningsmodellerne fungerer her som et eksempel på vejledningsdisciplinens grundbegreber, der i kurset dels får en rolle som redskaber til at kvalificere sig som lektievejleder, og dels tilbyder sig som referencerammer i lektievejledernes fremtidige handlingsrefleksion.

\section{Fase 4 - Generalisering}

Udviklingen af de nye vejledningsmodeller havde to formål: Det første var et praktisk pædagogisk mål, som handlede om at styrke Lektier Onlines http://www.lom.dk 
uddannelse af nye lektievejledere og kvalificere deltagernes vejledningskompetencer. Det andet var et videnskabeligt pædagogisk mål - at bidrage til en vejledningsdidaktik og udvikle lektiehjælp som et vejledningsfelt. Det første mål blev realiseret i form af udviklingen af de fem vejledningsmodeller, hvis evaluering og implementering viser $h ø j$ grad af økologisk validitet. Vejledningsmodeller er både implementeret som kursusmateriale, som del af det faglige indhold i uddannelsen af lektievejlederen, som redskaber til lektievejlederens faglige kvalificering og som referenceramme for handlingsrefleksion og heuristikker til håndtering af en vejledningssituation. Spørgsmålet er, om det pædagogiske designprojekt også har bidraget til at skabe ny videnskabelig viden? Det mener vi, at det har gjort på tre måder:

1) gennem udvikling af en teori om lektievejledning som et nyt vejledningsområde,

2) udvikling af en vejledningsdidaktik på lektievejledningsområdet og 3) udviklingen af fem vejledningsmodeller samt modellen Vejledningsformer.

I projektet har vi udviklet en forståelse og definition af lektievejledning som et nyt vejledningsområde på linje med de etablerede vejledningsområder som erhvervsfaglig-, opgavefaglig-, personlig- og studie-/ erhvervsvejledning. Lektievejledningen, som vejledningsområder definerer vi, som dialogisk eller konsultativ vejledning designet til at støtte elever $i$ at foretage relevante valg i deres forståelse og løsning af skolerelaterede opgaver med det mål at styrke deres faglige handleberedskab og mod på læring. I modellen 'Vejledningsformer' har vi udarbejdet en model, der dels kortlægger de forskellige lektievejledningsformer og dels beskriver vejledningsformernes karakteristika med hensyn til, om vejledningen foregår online/offline og konsultativ/dialogisk.

Ligeledes har artiklen bidraget til modellering samt definition af vejledningsdidaktik indenfor lektievejledningsområdet i form af teorier og metoder, der kan støtte og vejlede en lektievejleder i forståelse af vejledningssituationens vilkår og problemstillinger, i valg af vejledningsmetoder og $\mathrm{i}$ udmøntning af en individualiseret vejledning med det mål at styrke elevers faglige handleberedskab og mod på læring.

De fem vejledningsmodeller kan både fungere som teoretisk referenceramme i uddannelse af lektievejledere og som analytiske og generiske redskaber, der kan støtte lektievejlederen i deres håndtering af praksis og kritiske refleksion over praksis. De kan derfor være med til at uddanne lektievejledere som "reflekterede praktikere", der både formår at reflektere i deres praksis og over deres praksis, jf. Schöns begreber refleksion-ihandling og refleksion-over-handling (Schön, 2001). Refleksion-overhandling forstår Schön som den refleksion, der gør professionelle i stand til at håndtere usikre og komplekse praksissituationer. Det er netop den refleksion, som kursusafholderen mener, at kursusmaterialet med de udvik- 
lede vejledningsmodeller styrker, når hun siger at materialet gav "en enorm god forståelse for, hvad du gør i situationen, og det så ud som om lektiehjælperen fik en klarere forestilling om, hvad forløbet i en session er, og hvad man skal være obs på".

En lektievejledningsdidaktik har overordnet som formål at åbne og kvalificere en lektievejleders vejledningsmuligheder og styrke ham i at forstå, analysere, tage beslutninger om, håndtere og reflektere over en vejledningssession, der i princippet er unik og uforudsigelig. Særlige refleksionskategorier i håndteringen af en lektievejledningssession er de kategorier der fremgår af vejledningskompasset: hvem er lektievejlederen som lærende og hvad er hans faglige forudsætninger, hvad er hans lektie og dens særlige udfordring for eleven, hvilken vejledning - og valg af vejledningsstrategier - kan styrke elevens lektiearbejde og hvordan kan vejledningssessionen bidrage til elevens motivation til at arbejde videre med lektiens udfordringer.

\section{Konklusion}

Denne artikel har bidraget til beskrivelsen af lektievejledning som et nyt vejledningsfelt, der kræver en ny og særegen vejledningsdidaktik. Artiklen præsenterer et fagsprog og vejledningsmodeller til forståelse og håndtering af lektievejledning som et nyt vejledningsfelt. Endvidere har vi demonstreret, hvordan vi som forskerteam metodisk har fortolket og udmøntet den pædagogiske designforsknings metode. Potentialet i arbejdet med designeksperimenter som metode til udvikling af ny pædagogisk praksis og teori kan perspektiveres af Gravemeijer og Cobb, der siger at:

[...] design experiments can serve as the context for the development of theories or theoretical frameworks that entail new scientific categories that can do useful work in generating, selecting, and assessing design alternatives. The development of a conceptual framework to describe the phenomena under study is an essential part of a scientific endeavor. (2006, p. 52).

Nye videnskabelige kategorier har i den pædagogiske designforskning en dobbeltrolle, idet de både skaber mening over, hvad der foregår i en aktuel pædagogiske praksis og samtidigt kan fungere med Gravemeijers og Cobbs formulering som "guidelines or heuristics for instructional design" (2006, p. 63). De vejledningsmodeller, som er udviklet i forskningsprojektet, kan altså både fungere som analytiske kategorier til at forstå og kommunikere om den praksis, som lektievejledning er. Samtidig kan de bruges generisk som heuristikker og guidelines til udvikling af nye fremtidige praksisser. 


\section{Referencer}

Akker, J. v. d., Gravemeijer, K., McKenney, S., \& Nieveen, N. (2006). Educational Design Research. London: Routledge.

Amiel, T., \& Reeves, T. C. (2008). Design-Based Research and Educational Technology: Rethinking Technology and the Research Agenda. Educational Technology \& Society, 11(4), 29-40.

Anheier, H. K. (2005). Nonprofit Organizations: Theory, Management, Policy. London: Routledge.

Bannan-Ritland, B. (2003). The Role of Design in Research: The Integrative Learning Design Framework. Educational Researcher, 32(1), 21-24.

Benyon, D. (2013). Designing Interactive Systems: A comprehensive guide to HCI, UX and Interaction Design (3.rd edition ed.). Harlow: Pearson Education.

Bjørndal, C. R. P. (2011). Hva slags kompetanse trenger veilederen? Tre alternative forståelser. In T. J. Karlsen (Ed.), Veiledning under nye vilkår: skapende prosesser i møtet mellom veileder og veisøker (pp. 140-156). Oslo: Gyldendal Akademisk.

Bjørndal, K. E. W. (2014). Pædagogisk designforskning - en forskningsstrategi til at fremme bedre undervisning og læring (C. M. Christensen, Trans.). In M. Brekke \& T. Tiller (Eds.), Læreren som forsker: indføring i forskningsarbejde i skolen (pp. 245-257). Aarhus: Klim.

Bødker, K., Kensing, F., \& Simonsen, J. (2008). Professionel ITforundersøgelse : grundlag for brugerdrevet innovation (2 ed.). Frederiksberg: Samfundslitteratur.

Carlsen, D., \& Hansen, J. J. (Eds.). (2015). Digital læsedidaktik. København: Akademisk Forlag.

Carvalho, L., \& Goodyear, P. (2014). The Architecture of Productive Learning Networks. New York: Routledge.

Christensen, O., Gynther, K., \& Petersen, T. B. (2012). Design-Based Research - introduktion til en forskningsmetode i udvikling af nye Elæringskoncepter og didaktisk design medieret af digitale teknologier. Læring og Medier, 5(9).

Cobb, P., Confrey, J., diSessa, A., Lehrer, R., \& Schauble, L. (2003). Design Experiments in Educational Research. Educational Researcher, 32(1), 913.

Cooper, H. M. (1989). Homework. White Plains, New York: Longman.

Dale, E. L. (1998). Pædagogik og professionalitet. Århus: Klim.

Dohn, N. B., Degnebolig, H. S., Lindhardt, P. H., \& Lund, K.(2016): Lektier Online - didaktisk design af et uformelt online læringsrum? Læring \& Medier, 16 (forthcoming). 
Gaardsted, K., Frausing, G., Poulsen, A., Frydendahl, I., \& Linton, S. (2007). Lektiecaféer: et springbræt til en bedre skolegang. Århus/København: Kommunernes Skolebiblioteksforening, Biblioteksstyrelsen, Statsbiblioteket/BiblioteksCenter for Integration.

Godskesen, M., \& Kobayashi, S. (2015). Coaching doctoral students - a means to enhance progress and support self-organisation in doctoral education. Studies in Continuing Education, 1-17.

Gravemeijer, K., \& Cobb, P. (2006). Design Research from a Learning Design Perspective Educational design research (pp. 17-51). London: Routledge.

Gynther, K. (2011). ELYK metoder: Brugerdreven innovation og DesignBased Research. (Working paper). Retrieved from http://elyk.dk/wpcontent/uploads/2014/04/ELYK-metoder-Brugerdreven-innovationog-Design-based-Research.pdf

Hansen, J. J. (2012a). At designe e-læring - didaktiske perspektiver på uddannelsesdesign og didaktiske design. Læring og Medier, 5(9).

Hansen, J. J. (2012b). Danskfaget som undervisningsfag. Perspektiver på design og didaktik. Fredriksberg: Dansklærerforeningens forlag.

Hansen, J. J. (2016). Internettets metaforer. In N. B. Dohn \& J. J. Hansen (Eds.), Didaktik, design og digitalisering (pp. 65-88). Frederiksberg: Samfundslitteratur.

Hogue, R. J. (2013). Epistemological Foundations of Educational Design Research. In T. Bastiaens \& G. Marks (Eds.), Proceedings of E-Learn: World Conference on E-Learning in Corporate, Government, Healthcare, and Higher Education (pp. 1915-1922). Las Vegas, NV, USA: Association for the Advancement of Computing in Education (AACE)

Inglar, T. (1999). Lærer og vejleder: om pædagogiske retninger, vejledningsstrategier og vejledningsteknikker. Århus: Klim.

Jensen, J. F. (1998). Interaktivitet \& Interaktive Medier. In J. F. Jensen (Ed.), Multimedier, hypermedier, interaktive medier (pp. 17-42). Aalborg: Aalborg Universitetsforlag.

Kvale, S. (2007). Doing Interviews. London: SAGE.

Lauvås, P., \& Handal, G. (2006). Vejledning og praksisteori. Århus: Klim.

Lee, A., \& Green, B. (2009). Supervision as metaphor. Studies in Higher Education, 34(6), 615-630.

McAlpine, L., \& Amundsen, C. (2009). Identity and Agency: Pleasures and Collegiality among the Challenges of the Doctoral Journey. Studies in Continuing Education, 31(2), 109-125.

Michaelson, J. (2009). Online Homework Help: Evaluating the Options. Young Adult Library Services, 7(2), 25-28. 
Nielsen, G. F. (2011). Vejledningsdidaktiske grundbegreber og -positioner. In P. Plant, G. F. Nielsen, \& F. T. Hansen (Eds.), Vejledningsdidaktik. Valby: Schultz.

Novak, G. M., Gavrini, A., Christian, W., \& Patterson, E. (1999). Just-in-Time Teaching: Blending Active Learning with Eeb Technology. Upper Saddle River, NJ: Prentice Hall.

Plant, P., Fogh-Nielsen, G., \& Hansen, F. T. (Eds.). (2011). Vejledningsdidaktik. Valby: Schultz.

Rasmussen, T. (2012). Gratis lektiehjælp breder sig. Gymnasieskolen. Retrieved from http://gymnasieskolen.dk/gratis-lektiehj\%C3\%A6lpbreder-sig

Reeves, T. C. (2006). Design research from a technology perspective. Educational design research, 1(3), 52-66.

Richards, D., \& Viganò, N. (2012). Online Counseling. In Y. Zheng (Ed.), Encyclopedia of Cyber Behavior (pp. 699-713). Hershey, PA, USA: IGI Global.

Schön, D. A. (2001). Den reflekterende praktiker. Hvordan professionelle tænker, når de arbejder. Århus: Forlaget Klim.

Stålsett, U. E., Sandal, R., \& Tveten, W. (1994). Veiledningsmetodikk: om skoleutvikling i praksis (2nd ed.). Oslo: Tano.

The Design-Based Research Collective. (2003). Design-Based Research: An Emerging Paradigm for Educational Inquiry. Educational Researcher, 32(1), 5-8.

Walter, V. A., \& Mediavilla, C. (2005). Teens Are from Neptune, Librarians Are from Pluto: An Analysis of Online Reference Transactions. Library Trends, 54(2), 209-227.

Wang, F., \& Hannafin, M. J. (2005). Design-based research and technologyenhanced learning environments. Educational Technology Research and Development, 53(4), 5-23.

Wenger, E. (1998). Communities of practice: learning, meaning, and identity. Cambridge: Cambridge University Press.

Wisker, G., Robinson, G., Trafford, V., Warnes, M., \& Creighton, E. (2003). From Supervisory Dialogues to Successful PhDs: Strategies supporting and enabling the learning conversations of staff and students at postgraduate level. Teaching in Higher Education, 8(3), 383-397.

Yee, J., \& Bremner, C. (2011). Methodological bricolage: What does it tell us about design? Paper presented at the Doctoral Design Education Conference, Hong Kong Polytechnic, Hong Kong. Retrieved from http://nrl.northumbria.ac.uk/8822/. 